\title{
Knowledge of Primigravida about the Regularity of Examination of Pregnancy in Gayaman Village, Mojokerto Regency
}

\author{
Erfiani Mail \\ STIKes Majapahit, Mojokerto, East Java, Indonesia \\ Corresponding author: erfianimail@yahoo.co.id
}

\begin{abstract}
Background: The high rate of maternal and infant mortality is due to the low level of knowledge of mothers and the frequency of irregular pregnancy checks.

Purpose: The purpose of this study was to determine the knowledge of primigravida mothers about the regularity of prenatal care.

Methods: This type of observational research, according to the analysis is descriptive research. The population is all primigravida mothers who examined in Gayaman Village and the sample size of 30 respondents was taken based on total sampling technique. The instrument used was a questionnaire. Data collection is done through several stages, namely editing, coding, tabulating and scoring data, data collection was carried out on August 17-21 2018 in Gayaman Village, Mojokerto Regency.

Result: The results of the general data from primigravida mothers' knowledge of the regularity of prenatal care showed that of 30 respondents less than $50 \%$ had sufficient knowledge of 9 respondents $(30 \%)$. The data analysis here is enough because the education level of the respondents is lacking, so that in selecting and filtering the information received because the higher the level of education someone will influence the intellectual ability to choose information.

Conclusion: The conclusions from this study indicate that the knowledge of primigravida mothers about the regularity of prenatal care is sufficient. Therefore, it is necessary to improve communication, information and education from health workers in providing counseling on antenatal care, so that mothers understand more about the regularity of prenatal care.
\end{abstract}

Keywords: Mother's knowledge, Primigravida, Regularity of Examination

Received: February 21, 2019; Revised : March 9, 2019; Accepted: March 17, 2019

How to Cite: Mail, E. (2019). Knowledge of Primigravida about the Regularity of Examination of Pregnancy in Gayaman Village, Mojokerto Regency. Journal of Nursing Practice. 2(2). 123-129.

https://doi.org/10.30994/jnp.v2i2.55 


\section{BACKGROUND}

Pregnancy is a physiological and natural process. The period of pregnancy starts from conception until the birth of the fetus. The normal duration of pregnancy is 280 days or 40 weeks (10 months). Pregnancy is divided into three quarters (trimester), namely pregnancy in the first quarter occurs between 0-12 weeks, pregnancy in the second quarter between 12-28 weeks, third quarter between 28-40 weeks (F, Gary Cuningham, 2006: 2).

Antenatal care is care or care given to pregnant women before birth, which is useful to facilitate healthy and positive outcomes for pregnant women and their babies by establishing a trusting relationship with mothers, detecting life-threatening complications, preparing for birth and providing health education. Antenatal advice is important to ensure the natural process of birth is normal and healthy, both for the mother and the baby to be born (Pusdiknakes, 2002: 1).

Regularity of prenatal care is the most important component of health services to reduce the Maternal Mortality Rate and Infant Mortality Rate (RI Ministry of Health, 2001: 1). The high rate of maternal and infant mortality is partly due to the low level of knowledge of mothers and the frequency of irregular pregnancy checks. Regularity of prenatal care can be shown through the frequency of visits, it turns out this is a problem because not all pregnant women routinely check their pregnancies, especially normal pregnant women, so that abnormalities that arise in pregnancy are not detected as early as possible. There are several factors that cause why pregnant women are less motivated in carrying out regular and timely prenatal care, among others: lack of knowledge of pregnant women about regular pregnancy checks, busyness, lack of facilities for maternal services, poor medical care, lack of trained personnel (Sarwono, 2002: 22).

According to Syafudin (2001), clarifying pregnant women in the status of mild, moderate and severe risks, can not be used as a benchmark anymore, because all pregnant women are at high risk, even though pregnancy runs normally, but complications usually occur without predictions in labor. Therefore, every pregnant woman must check herself regularly and get optimal midwifery services. Providing services to every pregnant woman is a real strategy in an effort to increase the motivation of pregnant women about the importance of regular prenatal care (Syaifudin, 2001: 98).

Based on the results of a preliminary study in Gayaman Village, Mojokerto Regency, there were 30 pregnant women, only 11 pregnant women $(47 \%)$ who regularly had their pregnancies and 19 pregnant women $(53 \%)$ who did not regularly check their pregnancies. Regularity in prenatal care has an important role in ensuring that the mother can receive the care she needs and the plan of action should complications occur.

Antenatal care is important to ensure that the natural process continues to run normally during pregnancy. WHO estimates that around 15\% of all pregnant women will develop pregnancy-related complications and can be life threatening. Therefore, every pregnant woman requires at least four visits during the antenatal period. The main goal of antenatal care is to prepare the mother and baby in a healthy state by building a relationship of trust with the mother, detecting life-threatening danger signs, preparing birth and providing education to the mother (Pusdiknakes, 2002: 2). 


\section{OBJECTIVE}

The purpose of this study was to determine the knowledge of primigravida mothers about the regularity of prenatal care.

\section{METHODE}

This research is an observational descriptive study conducted in August 2018. This study uses primary data, which was collected by filling out questionnaires. In this study the population was all primigravida mothers who examined in Gayaman Village, Mojokerto Regency in August 2018 as many as 30 people. In this study using nonprobability sampling, total sampling type. Data collected is analyzed using frequency distribution, which is through grouping data into several groups or classes in a format called frequency tables

\section{RESULT}

Table of knowledge about antenatal care

\begin{tabular}{ccc}
\hline Knowledge level & f & \% \\
\hline Very Good & 5 & 16,7 \\
Good & 4 & 13,3 \\
Enough & 8 & 26,7 \\
Less & 7 & 23,3 \\
Very Less & 6 & 20 \\
\hline
\end{tabular}

Table of knowledge about antenatal care schedules

\begin{tabular}{ccc}
\hline Knowledge level & f & \% \\
\hline Very Good & 2 & 6,6 \\
Good & 5 & 16,7 \\
Enough & 5 & 16,7 \\
Less & 7 & 23,3 \\
Very Less & 11 & 36,7 \\
\hline
\end{tabular}

Table of knowledge about the place of antenatal care

\begin{tabular}{ccc}
\hline Knowledge level & f & \% \\
\hline Very Good & 7 & 23,3 \\
Good & 4 & 13,3 \\
Enough & 6 & 20 \\
Less & 8 & 26,7 \\
Very Less & 5 & 16,7 \\
\hline
\end{tabular}

Primigravida mother's knowledge table about regular pregnancy checks

\begin{tabular}{ccc}
\hline Knowledge level & f & \% \\
\hline Very Good & 4 & 13,3 \\
Good & 6 & 20 \\
Enough & 9 & 30
\end{tabular}




\begin{tabular}{ccc} 
Less & 8 & 26,7 \\
Very Less & 3 & 10 \\
\hline
\end{tabular}

Based on the table above shows that of the 30 respondents more than 50\% were knowledgeable about the Pregnancy Examination Regularity were 9 respondents (30\%). Based on the results of the study in table 4.8 shows that the level of knowledge of mothers is influenced by several factors including the factors of age, education, information, and sources of information.

The mother's knowledge about the regularity of pregnancy examinations mostly has less knowledge. This can be seen from 30 respondents aged 20-30 years 26 respondents (86.6\%), ages like this cause respondents to be less mature in choosing and filtering information received because of increasing age a person will influence the intellectual ability to receive information. Age is the age that starts from the time of birth until when he will be birthday. The more the age, the level of maturity and strength of a person will be more mature in thinking and in terms of public trust that more mature will be more trusted than people who are not mature enough. This is a result of experience and maturity of his soul. This is in accordance with the theory which states that the more the age, the level of maturity and strength of a person will be more mature in thinking and working (Notoatmodjo, 2003: 122).

The low level of knowledge is also influenced by the level of education. This can be seen from 30 respondents who have never received information about regular pregnancy checks more than 50\% have enough knowledge 16 respondents (53.3\%), the higher the level of education a person the easier they receive information and ultimately more knowledge it has.

The low level of knowledge is also influenced by information. This can be seen from 30 respondents who had received information about regular pregnancy checks, most of which had very good knowledge of 26 respondents $(86.7 \%)$, where respondents could only receive information obtained only, did not have the initiative to seek more recent information.

Knowledge is also influenced by sources of information. This can be seen from 30 respondents, more than $50 \%$ had received information from health workers having sufficient knowledge 12 respondents (46.3\%). Information can be obtained at home, organizational institutions, print media and health services. Knowledge and technology require information while producing information. If knowledge develops very quickly, information develops very quickly too (Kartono, 2006: 64).

Pregnant women do not have to be motivated by counseling from health workers but must also seek from other sources, for example by reading books, and other media.

\section{DISCUSSION}

\section{Characteristics of Respondents Based on Definition of Pregnancy Examination Regularity}

Based on the results of the study showed that of the 30 respondents more than $50 \%$ were knowledgeable about the notion of regular pregnancy check-ups, namely 8 respondents (26.7\%). According to Mubarok (2007: 28) Knowledge is the result of remembering things, including recalling events that have been experienced either intentionally or unintentionally and this happens after people make contact or observation of a particular object. 
Basically the notion of prenatal care is the discipline or compliance of pregnant women to monitor supervision before the child is born (Hoetomo, 20005: 1).

This is because mothers do not understand the meaning of regular pregnancy checks, so Health Workers must increase their efforts in communicating with everyone, especially pregnant women.

\section{Characteristics of Respondents Based on Pregnancy Examination Schedule}

Based on the results of the study in table 4.6, it shows that more than $50 \%$ of respondents have less knowledge about pregnancy check-up schedules, namely 11 respondents $(36.7 \%)$.

Pregnancy checks are carried out at least four times during pregnancy. In the first trimester 1 time, the second trimester 1 time, and the third trimester 2 times (Prawirohardjo, 2006; 90).

It can be seen that there is still a lack of knowledge of primigravida mothers about the regular schedule of prenatal care because there is still less experience and limited knowledge. Experience is a source of knowledge or a way to obtain truth and knowledge. This is done by repeating the experience gained in solving problems faced in the past. People who have experience will have good knowledge when compared to people who have no knowledge in any way (Notoatmojo, 2003, 129).

Thus, as a health worker, they must notify pregnant women about the correct check-up schedule, so that pregnant women can routinely check their womb on schedule.

\section{Characteristics of Respondents by Pregnancy Examination}

Based on the results of the study in table 4.7, it shows that more than $50 \%$ of respondents have less knowledge about the place of pregnancy examination, namely 8 respondents $(26.7 \%)$.

It can be seen that this knowledge of primigravida mothers about the place of pregnancy examination is less due to limited experience, information, or knowledge. Because according to its function, knowledge is a basic impulse to be curious, to seek reasoning, and to organize its experience. The existence of elements of experience that were initially inconsistent with what is known by the individual will be compiled, reorganized or changed in such a way that a consistency is achieved (Azwar, 2005: 54).

Pregnant women can get their pregnancies checked by: obstetricians, general practitioners, midwives, midwives nurses, and trained TBAs. In one community such as Indonesia there are health centers such as: Puskesmas and KIA, Polindes, Posyandu, where a pregnant woman can check her pregnancy (Mas'udah, 2006: 1).

As a Health Worker in conducting a pregnancy checkup, it requires a clean, comfortable, and bright place because this will make pregnant women comfortable in having their pregnancy checked.

\section{Characteristics of Respondents Based on Primigravida's Mother's Knowledge of Regular Pregnancy Examinations}

Based on the results of the study in table 4.8 shows that the level of knowledge of mothers is influenced by several factors including the factors of age, education, information, and sources of information. 
The mother's knowledge about the regularity of pregnancy examinations mostly has less knowledge. This can be seen from 30 respondents aged 20-30 years 26 respondents (86.6\%), ages like this cause respondents to be less mature in choosing and filtering information received because of increasing age a person will influence the intellectual ability to receive information. Age is the age that starts from the time of birth until when he will be birthday. The more the age, the level of maturity and strength of a person will be more mature in thinking and in terms of public trust that more mature will be more trusted than people who are not mature enough. This is a result of experience and maturity of his soul. This is in accordance with the theory which states that the more the age, the level of maturity and strength of a person will be more mature in thinking and working (Notoatmodjo, 2003: 122).

The low level of knowledge is also influenced by the level of education. This can be seen from 30 respondents who have never received information about regular pregnancy checks more than $50 \%$ have enough knowledge 16 respondents $(53.3 \%)$, the higher the level of education a person the easier they receive information and ultimately more knowledge it has.

The low level of knowledge is also influenced by information. This can be seen from 30 respondents who had received information about regular pregnancy checks, most of which had very good knowledge of 26 respondents $(86.7 \%)$, where respondents could only receive information obtained only, did not have the initiative to seek more recent information.

Knowledge is also influenced by sources of information. This can be seen from 30 respondents, more than $50 \%$ had received information from health workers having sufficient knowledge 12 respondents (46.3\%). Information can be obtained at home, organizational institutions, print media and health services. Knowledge and technology require information while producing information. If knowledge develops very quickly, information develops very quickly too (Kartono, 2006: 64).

Pregnant women do not have to be motivated by counseling from health workers but must also seek from other sources, for example by reading books, and other media

\section{CONCLUSION}

Based on the results of research at the Gedeg Health Center in Mojokerto Regency on 17-21 August 2018, it can be concluded that the knowledge of primigravida mothers regarding regular antenatal care is very good 4 respondents (13.3\%), both 6 respondents $(20 \%), 9$ respondents (30\%), less 8 respondents $(26.7 \%)$, less than 3 respondents $(10 \%)$. It can be concluded that more respondents are knowledgeable enough that is $30 \%$

\section{REFERENCES}

Arikunto, Suharsimi. (2003). Sikap Manusia. Yogyakarta : PT Rineka Cipta. Jakarta.

Azwar, S. (2005). Sikap Manusia. Yogyakarta : Pustaka Pelajar Offset.

Budiarto, Eko. (2002). Biostatistik.. Jakarta : EGC.

JHPIEGO, WHO. (2001). Konsep Asuhan Kebidanan. Jakarta : Pusdiknakes.

MacDaugall, Jane. (2003). Kehamilan Minggu Demi Minggu. Jakarta : Erlangga. 
Mansjoer. (2000). Kehamilan Lewat Bulan. Jakarta : EGC.

Mas'udah. (2006). Tempat Pelayanan Kehamilan. (www.fkm.undip.ac.id/data/index).

Mubarok, W, dkk. (2007). Promosi Kesehatan : Sebuah Pengantar Proses Belajar Mengajar Dalam Pendidikan. Yogyakarta : Graha Ilmu.

Notoatmodjo, Soekidjo. (2003). Pendidikan dan Perilaku Kesehatan. PT Rineka Cipta. Jakarta.

Prawirohardjo, Sarwono. (2006). Buku Acuan Nasional Pelayanan Kesehatan Maternal dan Neonatal. Jakarta : YBPSP.

Puspandari, Ririn. (2006). Peran Suami dalam Persiapan Persalinan Aman. (online) (http://www.dinkes DIY 2006, diakses 26 Maret 2008).

Sofyan, Mustika. (2006). Bidan Menyongsong Masa Depan. Jakarta : PP IBI. 